\title{
Sex Work, Essential Work: A Historical and (Necro)Political Analysis of Sex Work in Times of COVID-19 in Brazil
}

\author{
Betania Santos ${ }^{1,2}$, Indianarae Siqueira ${ }^{2,3}$, Cristiane Oliveira ${ }^{4}$, Laura Murray ${ }^{2,5,6, *}$, Thaddeus Blanchette ${ }^{2,6,7}$, \\ Carolina Bonomi ${ }^{8}$, Ana Paula da Silva ${ }^{2,6,9}$ and Soraya Simões $2,6,10$ (D)
}

1 Associação Mulheres Guerreiras (Warrior Women Association), Jardim Itatinga, Campinas, São Paulo CEP 13052-444, Brazil; Associ.mulheres.guerreiras@gmail.com

2 Coletivo Puta Davida, Rio de Janeiro CEP 20270-200, Brazil; indianaresiqueira@gmail.com (I.S.); thaddeus.blanchette@gmail.com (T.B.); anpaulasilva@id.uff.br (A.P.d.S.); Sosimoes01@gmail.com (S.S.)

3 CasaNem and Transrevolução, Rio de Janeiro, Rio de Janeiro CEP 22220-040, Brazil

4 Independent Sex Worker, Vila Mimosa, Rio de Janeiro, Rio de Janeiro CEP 20270-200, Brazil; aline.esteves.69@gmail.com

5 Center on Public Policy and Human Rights, Federal University of Rio de Janeiro (NEPP-DH/UFRJ), Rio de Janeiro CEP 22290-240, Brazil

6 Prostitution Policy Watch, Le Metro-Urban Ethnography Laboratory, Federal University of Rio de Janeiro, Rio de Janeiro CEP 20051-070, Brazil

7 Institute of Biodiversity and Sustainability, Federal University of Rio de Janeiro, Macae, Rio de Janeiro CEP 27965-045, Brazil

8 Campinas State University (UNICAMP), Campinas, São Paulo CEP 13083-896, Brazil; bonomicarolinamg@gmail.com

9 Licenciatura Interdisciplinar em Educação do Campo/INFES/UFF, San Antônio de Pádua, Rio de Janeiro CEP 28470-000, Brazil

Citation: Santos, B.; Siqueira, I.; Oliveira, C.; Murray, L.; Blanchette, T.; Bonomi, C.; da Silva, A.P.; Simões, S. Sex Work, Essential Work: A Historical and (Necro)Political Analysis of Sex Work in Times of COVID-19 in Brazil. Soc. Sci. 2021, 10, 2. https://dx.doi.org/10.3390/ socsci10010002

Received: 17 October 2020 Accepted: 15 December 2020 Published: 24 December 2020

Publisher's Note: MDPI stays neutral with regard to jurisdictional claims in published maps and institutional affiliations.

Copyright: (C) 2020 by the authors. Licensee MDPI, Basel, Switzerland. This article is an open access article distributed under the terms and conditions of the Creative Commons Attribution (CC BY) license (https: / / creativecommons.org/ licenses/by/4.0/).
10 Institute for Urban and Regional Planning and Research, Federal University of Rio de Janeiro (IPPUR/UFRJ), Rio de Janeiro CEP 21941-909, Brazil

* Correspondence: laura.rebecca.murray@gmail.com

\begin{abstract}
Brazil has made international headlines for the government's inept and irresponsible response to the COVID-19 pandemic. In this context, sex worker activists have once again taken on an essential role in responding to the pandemic amidst State absences and abuses. Drawing on the theoretical framework of necropolitics, we trace the gendered, sexualized, and racialized dimensions of how prostitution and work have been (un)governed in Brazil and how this has framed sex worker activists' responses to COVID-19. As a group of scholars and sex worker activists based in Rio de Janeiro and São Paulo, we specifically explore the idea of sex workers as "essential workers", but also of sex work as, essentially, work, demonstrating complicities, differences, and congruencies in how sex workers see what they do and who their allies in the context of the 21st century's greatest health crisis to date.
\end{abstract}

Keywords: prostitution; COVID-19; sex worker activism; labor laws; Brazil

\section{Introduction}

26 March, 2020. "Brazil Can't Stop" begins circulating on social media a month after Milan's mayor launched a similar campaign just before deaths skyrocketed in that Italian city. The Brazilian video begins by saying that "for Brazil's nearly 40 million autonomous workers, Brazil cannot stop". ${ }^{1}$ A parade of images follows: a man selling bikinis on a beach, woman in a market stall, a young man selling a selfie stick, domestic workers. The majority of the people shown are Black and engaged in precarious labor. The images then shift to hospital waiting rooms. The narration insinuates that social isolation means stopping crucial care and services. The tone is threatening, yet aims for uplifting nationalism.

\footnotetext{
1 https://www.youtube.com/watch?v=hQQZE7LQIGk.
} 
The video ends by saying, "For those who defend Brazilian lives and the possibility for all to live with quality, health, and dignity, Brazil definitely cannot stop".

There are many striking features about this video, not the least the fact that it was immediately suspended by a federal judge for going against the Federal Government's own Ministry of Health's guidelines. ${ }^{2}$ The President's communication team alleged that they never created the campaign, though Bolsonaro's son, Senator Flavio Bolsonaro, shared it online. This is, of course, not the only thing the Bolsonaro government has denied. Its negation of the new coronavirus and its deadly effects have become global headlines. An apparent contradiction is exposed by the video, however. On the one hand, it highlights populations and issues that Bolsonaro was elected to not care about (Blacks, the poor, Brazil's public health system - the SUS - etc.). On the other, support for this message came from a series of elite, white businessmen. These men recorded their testimonies defending the idea that Brazil could not stop merely to save 4000-7000 lives while themselves in isolation at their private ranches.

As we finalize this article in December 2020, nearly 180,000 Brazilians have died from COVID-19, a disproportionate number of which are Black and poor (Santos et al. 2020b). This suggests that the campaign video is not a contradiction after all. By encouraging the country's most vulnerable workers to break social isolation at a time when public hospitals were overwhelmed, it is a perverse display of postcolonial scholar Achille Mbembe's concept of necropolitics (Mbembe 2003), valuing and protecting certain bodies while condemning others to death. Necropower is primarily exercised through the threat of death and right to expose to death and/or kill. Mbembe argues that rather than exceptional, sovereignties built on projects of destruction and death are the norm in contemporary political spheres (Mbembe 2003, p. 13).

In this paper, we draw on this concept of necropolitics and recent analyses of Bolsonaro's response to COVID-19 as an emergent form of "non(governance)" (Ortega and Orsini 2020) to trace the gendered, sexualized, and racialized dimensions of how prostitution ${ }^{3}$ has been (un)governed in Brazil and how sex workers have responded to the pandemic within this context. Specifically, we explore the idea of "essential workers", inspired by co-author Betania Santos' activism, which guaranteed that sex workers received the H1N1 vaccine as "essential workers" during the early months of the pandemic. As in many contexts, the mobilization of the concept of "essential" has laid bare inequalities in Brazil's labor structure. We argue that Brazilian elites' long-standing distaste for the country's working class, deeply rooted in Brazil's colonial and slaveocratic history, has resulted in a contradictory system of (non)regulation of sex work in Brazil that has been thrown into stark relief by the COVID-19 crisis and provoked differing sex worker responses based on differing notions of sex, labor, and sex-as-labor.

While scholars have increasingly looked to necropolitics as a framework for analyzing government responses to COVID-19 in Brazil (Ortega and Orsini 2020; Santos et al. 2020a), there is a paucity of research looking at this at the intersections of labor, gender, and sexuality politics. By locating our discussion within a historical and political analysis of prostitution and labor, we are in dialogue with international sex work scholarship that has looked critically and historically at regulatory models of prostitution (Sanders et al. 2017; Dewey and Kelly 2011; Mac and Smith 2018). We also see it as contributing to an important body of emerging work on prostitution and COVID-19 that has looked at sex workers fundamental, and many times highly vulnerable, role in responding to the epidemic (Platt et al. 2020; Lam 2020; Gichuna et al. 2020) in the absence of a state response globally.

The manuscript was written entirely during the COVID-19 pandemic through exclusively virtual means. Co-authors based in Rio de Janeiro have been collaborating together as part of research and activism on prostitution in Brazil since 2013 as part of the Prosti-

2 https://www.dw.com/pt-br/justiça-suspende-campanha-o-brasil-não-pode-parar/a-52948560.

3 By "prostitution", we mean the sale of direct, physical sexual acts, differentiated from a more generalized "sex work", which can include phone sex and stripping. 
tution Policy Watch extention project at the Federal University of Rio d Janeiro and the Coletivo Puta Davida, a collective that evolved out of the NGO Davida, founded by prostitute activist Gabriela Leite in $1992 .{ }^{4}$ For our analyses, we relied on literature reviews and archival research for the theoretical and historical components of the piece, as well decades of our ethnographic research on prostitution in Brazil. Each case study was written in partnership with the activists and sex workers featured. This process included interviews with activists that were later transcribed, as well as, especially in the case of the CasaNem, the incorporation and translation of previously written texts about their responses to the COVID-19. We chose to write in the third person and included quotes from the interviews and conversations between sex worker authors to emphasize their direct perspectives on sex work and on one another's perspectives of work. We have done our best to highlight these dialogues and differences within the text.

We start with an overview of the laws surrounding prostitution in Brazil, weaving in a discussion about the social stratification of Brazil's labor force to show how the maintenance of prostitution in the penal code-despite it being a recognized profession—says as much about the country's colonial administrative structure as of the moralities surrounding sexuality. We highlight the central role of sex worker activists in changing public debates and pushing legislation to regulate the profession, in addition to their protagonism in developing Brazil's internationally renowned response to HIV / AIDS. We then enter into a theoretical analysis linking this historical context with the government's response to the COVID-19 pandemic, prior to presenting three case studies of what the pandemic has looked like in Rio de Janeiro and São Paulo - the two states, to date, with the highest number of cases. In each study, we highlight both different perspectives on prostitution as work and the paradoxical relationships forged between sex workers, the State, and parastatal agencies both before and through the pandemic, up to the present. We conclude by analyzing how work relations and prostitutes' attitudes towards sex as work have impacted upon these sex working communities' ability to combat the pandemic.

\section{Sex, Work, and the Law in Brazil}

\subsection{Labor and Criminal Laws}

In general, Brazilian law has seen prostitution through the lens of lenocinio (third party participation in the profits of sex work) or "trafficking in persons". The sale of sex has only very recently been legally conceived of as a form of labor. Established shortly after the founding of Brazil's first Republic in the 1890s, reified under Getúlio Vargas' Estado Novo in the 1940s, and refined and consecrated in the re-democratization of the 1980s-2000s, Brazil's prostitution laws are simultaneously abolitionist, regulationist, and prohibitionist. They are abolitionist in the sense that the country has committed itself, through international treaties, to eliminating prostitution. The legal code formally recognizes this by criminalizing the activities of third parties, the establishment of brothels, and recruitment for prostitution (among other things), but not criminalizing the sale of sex itself, as-according to the abolitionist perspective - this would unduly (re)victimize women who sell sex.

Brazilian prostitution laws have been noble in declared intent, but vague in particularities (Blanchette and Pereira 2017). What this has meant is that police and municipal officials have practically administrated sex work in local contexts through the expedient of deciding against whom and what they should apply the law. This historically has meant sex workers' families, partners, and close associates, not the owners of the clubs, saunas, hotels, and bars prostitutes frequent and who profit from sex work. These businessmen have been able to avoid legal harassment by paying a portion of their profits to the police, either legally—through licensing fees for clubs, boarding houses, etc.—or illegally through a payoffs system, in a form of "unregulated regulationism" (Blanchette et al. 2017). People who sell sex outside of the times and places police permit, however, are liable to be subject

4 Blanchette, Murray, Silva and Simões are also all part of an extension project to combat COVID-19 created by the UFRJ-Macaé, and specifically, this project's working group on Sex Work Street Populations. 
to the full force of the law, as well as extrajuridical sanctions up to and including rape, physical violence, and, most commonly, illegal arrests (Blanchette et al. 2017).

This use of selective law enforcement to police laborers is not unique to prostitution. The poor in Brazil, and Black Brazilians in particular, have long been constructed as a "dangerous class" (Chaloub 1996). In the late 19th century, this view was enshrined in colonial structures subordinating recently freed slaves through administrative controls (workers' cards, IDs, etc.), police repression, and racist political rhetoric (Chaloub 1996). These strategies were similar to those simultaneously being employed by police against prostitutes. Late 19th and early 20th century discussions regarding the regulation of prostitution were also medicalized by government and public health officials' attempts to control a syphilis epidemic (Carrara 1996). Up through the 1950s and 60s, sex workers in Rio were required to carry ID cards and undergo obligatory STI exams in order to work, all extra-juridically organized through the Rio de Janeiro "Delegacia de Costumes" (the city vice squad). As we have argued elsewhere (Blanchette et al. 2017), this (un)official regulation of a quasi-legal activity by the police is very particular to Brazil. What is important in the context of the present article is that prostitution was administrated by the State and its parastatal allies (Amar 2013) in a manner similar to the ways in which the State sought to control workers, particularly the masses of newly liberated Black and brown Brazilians.

Prostitutes-like many poor, informal laborers-were frequently persecuted and harassed as "non-workers" through vagrancy laws. Until the 1980s, Brazilians could be jailed for up to three months for "vagrancy" unless they could show legal means of support. For unemployed adult women, this meant a male partner willing to be identified as a husband (whether or not the couple was married "on paper"). Through use of "vagrancy" laws, police could jail women working independently or in places designated as "whore free zones".

Police lost vagrancy as legal tool for the administration of sex work with the suspension of Brazil's vagrancy laws following the end of the military regime in the 1980s. Since then, other laws have been used to keep prostitution "within bounds"-i.e., in the areas and times where it is permitted and where, crucially, the police or other authorities profit from it. Laws that define prostitution as a form of "non-work" or as an activity undertaken by "the dangerous classes", which threatens hegemonic moralities (Chaloub 1996), are thus combined with discretionary policing to create a situation in which sex work is simultaneously omnipresent and yet largely restricted to times and places defined by municipal authorities.

\subsection{Legislative Struggles and Prostitute Activism}

Brazilian sex workers (and, in particular, prostitute activists) have always seen their occupation as part of a larger universe of labor and law. Above all, given the situation described above, they believed that it was necessary for Brazil to legally recognize prostitution as work, removing it from the sphere of law enforcement and thus from the exploitation of sex work by State and parastatal actors.

Sex workers first organized in Brazil in the 1970s. In São Paulo, this took the form of protests organized by a young sex worker named Gabriela Leite. Leite mobilized her colleagues against police violence and impunity in the Boca do Lixo area where she worked (Leite 2009). In Brazil's north, in Belém de Pará, Lourdes Barreto was simultaneously organizing her colleagues against the repeated violent raids and abuses of police in the Bairro Campina district. Gabriela and Lourdes would meet at an event held by the Catholic Church in the mid-1980s. After abandoning the Church for its victim-centered approach to prostitution, the women organized Brazil's first national encounter of prostitutes called, "Speak, Women of the Life" in Rio de Janeiro in 1987 (Leite 1996). The movement founded by Leite and Barreto was built on assuming that sex work was respectable work, combating stigma, and refusing the label of "victim" so frequently attributed to prostitutes, independent of their work contexts (Leite 1996). As part of this project, Leite and Barreto reclaimed 
the terms "prostitute" and "puta" (whore) as part of the politics of destigmatizing sex worker identities.

The emergence of the sex worker movement coincided with the beginning of the AIDS epidemic and the redemocratization of Brazil after three decades of military rule (Murray et al. 2018a). Leite and Barreto's involvement in the development of the country's first national level HIV prevention program was critical in establishing sex workers' role as protagonists in implementing a response to the epidemic on a national scale (Murray et al. 2018b). The women situated sex workers as essential to HIV / AIDS prevention, highlighting their extensive social and labor networks. This laid the groundwork for mobilizations that flourished over the following two decades. Sex worker rights organizations were founded throughout Brazil, decisively contributing to the struggle against HIV and for sex workers' rights.

During this period, the federal government supported these organizations through cooperative agreements with international agencies such as the World Bank. As Simões notes (Simões 2010a), on the one hand, sex worker organizations became parastatal partners of the state through their preventive actions as "muliplicadoras" in red light districts; on the other, the State's institutional and financial support contributed to strengthening sex workers' collective identity. This process would be consolidated in 2002, when "Sex Professional" was included in the Brazilian Ministry of Labor and Employment's Classification of Occupations (the $\mathrm{CBO}$ ). ${ }^{5}$ The specific outlines of sex work were defined in a joint workshop with leaders from the Brazilian Prostitutes' Network (RBP), including Leite and Barreto. The resulting definition included specificities and characteristics that reinforced the centrality of prevention and care for and by sex workers. As Simões (who participated in the meeting as an ethnographer) notes, the workshop constructed prostitution as a professional category that labored in areas far beyond sex, highlighting activities such as "using and distributing condoms", "washing miners' clothes," "giving advice," and "denouncing discrimination".

The CBO's definition expanded the job's frontiers and emphasized its social importance as labor (Simões 2010a). Prostitution thus began to be seen as something more than a simple inevitability: it became understood as an option. The Brazilian Labor Code's recognition of sex work opened up new perspectives, particularly with regards to the responsibilities workers took on by opting to do sex work as professionals. Self-care was situated as a primary condition for the responsible exercise of sex work and not as an individual duty, undertaken to keep contagious STDs away from "the family".

This official recognition of sex work as an occupation (ironically, administratively as part of the group of service, domestic, small business, and security workers featured in the "Brazil Can't Stop" video) was an important milestone that, more pragmatically, allowed prostitutes to obtain retirement and other benefits. It did not, however, create a regulatory policy that could completely guarantee sex workers' full labor rights. The continued criminalization of all that surrounds it has also meant that prostitution continues in a state of professional, legal, and even subjective ambiguity. The very nature of the structure of the State in Brazil is to manage its "subjects" through a series of complicated and often contradictory laws that are both impossible to follow and enforce and highly dependent on the interpretation of those in power (Souza Lima 2002) This has created many seemingly contradictory situations, thought impossible in other national contexts, in which criminalization co-exists with collaboration, and repression with protection (Murray 2014).

\subsection{Sex Workers, Not Government Workers}

The title of this section paraphrases a 2011 statement by the Brazilian Prostitutes' Network (RBP), produced at a regional conference in Belém on 6 August, 2011 (Rede Brasileira de Prostitutas 2011): "We are sex professionals, not government workers". The statement outlined 10 deliberations of the RBP regarding their priority issues, marking the moment

5 The CBO's description of sex work can be found at http://www.mtecbo.gov.br/cbosite/pages/pesquisas/BuscaPorTituloResultado.jsf. 
when the Network decided to stop applying for federal funding for AIDS projects. While the RBP recognized the importance of the National AIDS Program within the prostitutes movement, they also expressed their dissatisfaction with the way this relationship had evolved. They believed that the "risk group" mentality they had fought against in the late 80 s and 90s had returned through projects "reinforcing [the notion of] prostitutes as spreaders of disease and distributors of condoms".

Prostitute leaders also felt that those who had been contracted as peer educators saw themselves more as health agents, motivated by income, as opposed to political organizers, motivated by the cause of sex worker rights. This dynamic distanced prostitutes from their colleagues (Leite et al. 2015). At the 2011 Belém meeting, leaders called for sex worker activists to go "back to the street corners" to construct a relationship with people who sold sex that moved beyond the role of "peer educator". They rejected the primacy of the role of prostitutes as government policy watchdogs and called upon the government to promote public policies for sex workers that went beyond health-related issues. They wanted policies that addressed the labor rights, human rights, and women's rights.

Unfortunately, the political scenario in Brazil has only gotten worse since 2011. The Brazilian Prostitutes' Network's demands to be contemplated in broader public policies have not been met (ABIA and DAVIDA 2013). The leftist Workers' Party government (PT) made concessions to a growing reactionary Evangelical conservative lobby to maintain power which made advancing progressive laws nearly impossible. The most relevant example perhaps being when Federal Congressman and close ally of the sex worker movement Jean Wyllys (PSOL) introduced a new bill, \#4211/2012, entitled the "Gabriela Leite Bill" that attempted to define the legally vague concept of "sexual exploitation" in order to fully decriminalize sex work and open paths for the legalization of brothels ${ }^{6}$ that ended up landing in the Congressional Committee on Human Rights where an Evangelical pastor, ally of Bolsonaro, had been named as the head. The bill was tabled, and in this climate, HIV prevention campaigns for gays (in 2012) and sex workers (2013) were censored (Leite et al. 2015), and the word "puta" (whore) ${ }^{7}$ was removed from the CBO's definition of sex work (ABIA and DAVIDA 2013).

In 2013, the sex workers' movement suffered an immeasurable loss with the death of Gabriela Leite. The Brazilian Prostitutes' Network continued, however, and was joined by two additional national organizations-The Central Unica de Trabalhadoras Sexuais (CUTSwhose name that is a take on one of Brazil's largest trade unions, CUT-Unified Center of Workers) and the Articulação Nacional de Profissionais do Sexo (ANPS-National Articulation of Sex Professionals). While many activists use the word "prostituta" or even "puta" (whore) in their talks and writings, the names of each national movement hint towards their political foci and perspectives regarding prostitution. The Brazilian Prostitute Network has defended the use of "prostituta" and "puta" since the 1987 National Encounter as part of a strategy of "taking words by the horns" (Leite 2013) to resignify them and confront the root causes of the whore stigma. CUTS, on the other hand, has focused labor rights arguments and the ANPS, for this same reason, chose to use the exact term used in the CBO (professional do sexo). Defending prostitution as work, however, is part of all three networks' political platforms, as exemplified by co-author Betania Santos' extensive work with labor unions (described below) and the writings of one of CUTS' founders, Monique Prada, on prostitution, feminism, and labor as part of a putafeminista platform (Prada 2018).

Sex worker rights organizations in Brazil had to diminish their activities as government support for HIV prevention work dwindled along with sources of international funding (Murray et al. 2018a). Preparation for sporting mega-events in 2012, 2014, and 2016

6 Nearly a decade earlier, in 2003, then, Federal Congressman Fernando Gabeira, at that point a member of the Workers' Party (Partido dos Trabalhadores - PT), introduced Bill \#98/2003 to fully decriminalize sex work, which was also eventually tabled by Congress.

7 While this might sound like a positive thing for anglophone readers, it is important to remember that the Brazilian sex workers' rights movement founded by Leite and Barreto has as one of its central points reclamation of the word "whore" as a marker of group empowerment through the reversal of stigmatizing symbolism. By eliminating "whore" from the CBO's definition of sex work in this context, the Federal Labor Ministry was obviously trying to distance itself from the political and polemical sex workers' struggle in Brazil. 
accelerated and increased gentrification and police repression (De Lisio 2013; Amar 2013; Mitchell Forthcoming), leading to one of the largest documented police raids in recent history in the Rio de Janeiro suburb of Niterói (Murray 2014). These processes-along with many others-have intensified as the country has become increasingly politically polarized. From 2016 on, Brazil has seen the impeachment of President Dilma Rousseff (denounced by many as a soft coup), the assassination of Black, bisexual, human rights activist and Rio de Janeiro city councilwoman Marielle Franco in March of 2018, and (seven months later) the election Jair Bolsonaro as president.

So far, the Bolsonaro regime has, ironically, brought a bit of respite to prostitution establishments in terms of organized state interventions and repression. This is largely because a significant portion of State pressure on establishments and those who sold sex in Brazil was coming through accelerated gentrification around the mega-sporting events and anti-human trafficking policy that, under the early years of the PT government, often conflated sex work with sexual exploitation and labor slavery. By the end of the PT era, however, sex workers had literally gained space at the decision-making table when it came time to define Brazil's new anti-trafficking laws. ${ }^{8}$ Partially because of this activism, the new laws focused on repressing forced labor under slavery-like conditions and not sex work. So far, the Bolsonaro government has been loath to conduct much activity in the anti-trafficking field, because this would necessarily require a re-imagining of "slave labor" in national anti-trafficking policy, and the Bolsonaro government's congressional allies in the agribusiness caucus do not want "slave labor" on the national agenda.

However, the Bolsonaro government's destruction of the Women's and Human Rights Ministries via their conflation under a new "family oriented" Ministry of Women, the Family, and Human Rights, headed by evangelical pastor and fierce anti-feminist Damaris Alves, indicates where the government would head if it could. This direction is probably best indicated by a bill from Congressman João Campos, an ally of Bolsonaro and major actor in the Evangelical Caucus that pushed Minister Damaris to power. His bill, currently tabled in Congress, would criminalize the purchase of sex. As we've described here, the Brazilian sex industry is largely controlled by the police and parastatal militias, which Mbembe notes are a contemporary feature of necropolitics (Mbembe 2003, p. 32) and widely recognized in Brazil as having connections to the Bolsonaro family (for a range of illegal activities, not prostitution specifically). ${ }^{9}$ A bill such as that proposed by Campos-if enacted-would give police even more discretionary power to crack down on forms of "unacceptable" sex work. Historical experience indicates that they would apply this newfound power to repressing independent prostitution, pushing sex workers venues that are strictly monitored and that pay off the police.

Although prostitution has yet to be singled out as a target by the Bolsonaro government, sex workers are feeling the effects of policies that consistently undermine constitutional protections for cisgender and transgender women in general-particularly in the fields of health, education, and abortion. ${ }^{10}$ There are no national statistics on prostitution in Brazil, yet the most recent nationwide study focused on sex work and HIV prevalence found that the lower the level of education, the lower price charged for sex, and older the age were all associated with higher odds for HIV infection (Szwarcwald et al. 2018), eco-

8 Co-author Blanchette represented Davida on both the state and federal anti-trafficking committees, in the latter case, together with Belo Horizontebased sex worker leader Aparecida Viera. Working with other grass-roots feminist and LGBT organizations in the committee, they were able to ensure that Brazil's new 2016 trafficking laws did not automatically conflate prostitution with trafficking. This section is based on Blanchette's on-going representative and ethnographic experiences in the political field of Brazilian State anti-trafficking policy as a member of the Rio de Janeiro state anti-slave labor committee.

9 These connections have been frequently highlighted by the Brazilian media and closely accompanied and researched by the bilingual online news outlet Intercept. See Glennwald and Pougy: https://theintercept.com/2019/03/18/jair-bolsonaro-family-militias-gangs-brazil/.

10 This is an immense topic that is far too large to tackle here. See Lia Zanotti's article (2020), where she provides readers with an overview of the Bolsonaro government's human rights policies, with a special focus on how these have affected women and Black and brown Brazilians (Zanotti 2020). 
nomic and social factors that initial studies also been found to be associated with increased vulnerability and morbidity to COVID-19 (Guimarães et al. 2020).

As we explore in the following section and the previously cited emerging body of research on sex work and COVID-19 has highlighted, sex workers as autonomous workers are particularly vulnerable in the pandemic, and Brazil has been no exception to this rule. Also similar to many countries (Sánchez et al. 2020), violence against women has increased significantly during the pandemic (Marques et al. 2020), and although there are no official statistics, through our networks we have noted more reports of violence and murder of sex workers. As we explore in the following section, COVID-19 has laid bare the extreme inequalities in Brazil that have only deepened as the pandemic has waged on without a hint of a coordinated national response, making it exemplary only as a politics of neglect and a politics of death.

\section{Neglect and Necropolitics}

The pandemic arrived in Brazil slightly over a year after Bolsonaro took power. It was immediately politicized and polarized by the President through an effective social media machine propelled by what is referred to as his "Hate Cabinet" that has systematically spread misinformation about the pandemic and encouraged subverting public health guidelines surrounding social distancing and mask-wearing. As Francisco Ortega and Orsini (2020) have noted, the shift in public health governance under Bolsonaro "might be best characterized as a conscious intensification of state neglect, in which the federal government can capitalize on a public health emergency to reassert its policies of dispossession" and in which "denialism (of COVID-19) merges with an acute awareness of whose harm is magnified in a public health crisis" (p. 1265). Ortega and Orsini, similar to other scholars and public health advocates (Santos et al. 2020b), highlight the necropolitical features of Bolsonaro's (non) governance of the pandemic, drawing on the influential work of Mbembe (2003) and data showing the much higher toll the virus is taking on Black, Indigenous, and poor Brazilians (Santos et al. 2020b).

In her work looking at the gendered necropolitics (Ahmetbeyzade 2008) of the Mexican government in the context of femicide against female factory workers and drug wars in Ciudad Juárez, Mexico, Melissa Wright notes how governmental authorities normalized violence against "public women" as inevitable and even justified (Wright 2011). In government discourses, "public women" associated female factory workers with negative stereotypes of sex workers as "contaminated" by their work outside the home and framed the women as sources, rather than victims, of violence. Within this perverse logic, Wright observes that "the deaths of public women represent a kind of public cleansing, as the removal of troublesome women restores the moral and political balance of society" (Wright 2011, p. 713).

Wright's analysis is useful for thinking about the gendered necropolitics currently governing Bolsonaro's response to COVID-19 and the Brazilian State's relationship to prostitution more broadly. As previously discussed, Bolsonaro has designed his administration to be around restoring morals to Brazil, and his denialism goes beyond the pandemic to also denying that structural racism and gender inequality exists in Brazil, dismissing such claims frequently as "mimimi" (loosely translated to whining). Applying Wright's analysis of "public women" discourse in Mexico to Brazil, the governments forceful rebukes of social distancing and insistence that the economy cannot stop in a context where poor, Black Brazilian women tend to be on the front lines of both the service and care industry remit a similar "public cleansing" and attempts at restoring moral and political order under a far-right, racist agenda (Santos et al. 2020b). Indeed, the hashtag \#bolsonarogenocida (bolsonarogenocide) has been used more than 100,000 times and has been the headline of innumerous editorials, protest chants, publications, and events denouncing the government's (non)response to the pandemic.

We would argue that Bolsonaro's (non)governance of the COVID-19 pandemic is only the most recent exercise in Brazilian necropolitics and symptomatic of an attitude that 
has been around for decades in the context of prostitution. As we have shown in the first part of this paper, neglect has been strategic and conscious, much like Ortega and Orsini observe Bolsonaro has been with regards to the effects of his denialism and negligence. Sex workers are often only of importance to the State insofar as they might either spread disease to "proper" families or assist the State in stopping that spread. It is within this context that sex workers have organized responses to the pandemic.

In the second half of this paper, we describe three case studies representing different takes on prostitution as essential work and the paradoxical relationships Brazilian sex workers forge with the State. Our first focuses on the Warrior Women organization in Campinas, São Paulo, describing sex workers' actions during the pandemic and the assemblage of Church, security, and health workers that victimized and recruited prostitutes as part of strategies of "protection" against the coronavirus. The second looks at CasaNem, a trans-occupation in Rio de Janeiro that has led outreach programs during the crisis, providing shelter and food to those who need it. During the pandemic, they were evicted from their squat by the military police. However, two weeks later, the state and municipal Rio de Janeiro LGBTQIA+ and diversity programs granted a permanent home for their shelter and outreach work. Finally, as a counterpoint to these two examples of sex worker-led activism, we look at the Rio de Janeiro red light district of Vila Mimosa, where sex workers, business owners, and parastatal forces organized after a legislative committee shut down the zona for fire code violations in December 2019. Here, we specifically focus on the discourses around prostitution as work that were mobilized in efforts to reopen the Vila, and then to support its women during the ensuing pandemic lockdown.

In all three cases, we can see protection, care, and advocacy on behalf of sex worker rights organizations and a simultaneous necropolitics, conducted by State structures. These intervene in sex workers' lives and labor under the guise of reducing "exploitation" and eliminating "dangerous" and "degrading" conditions, impeding sex workers' ability to work while simultaneously ignoring prostitutes as the pandemic ravages Brazil. As they did in the early years of the HIV epidemic, sex workers have organized themselves to provide food, cleaning supplies, and masks for their colleagues in the absence of an organized State response. It is in this sense that we argue that sex work is essential: not only as a profession, but also as one that maintains a central role in health education, care, and resistance. We use the phrase, "The Red Light District Can't Stop" as a counterpoint to Bolsonaro's campaign. In this case, "not stopping" doesn't mean continuing to produce capital under predatory neoliberal policies at all costs: it is about continuing to work to care for colleagues and prevent contagion. It recognizes the deep inequalities present in the broader Brazilian labor force and struggles to ensure that sex workers have access to all they need in order to safely work and care for themselves, their families, their colleagues, and their clients.

\section{The Red Light District Can't Stop: Sex Worker Organization Activities in Combatting COVID-19}

4.1. Warrior Women Association (Associação Mulheres Guerreiras-Unidas Pelo Respeito: AMG), Campinas-SP

The Associação Mulheres Guerreiras- Unidas pela Respeito (AMG) was founded in 2007 to promote the human and sexual rights of sex workers in the city of Campinas (São Paulo). The Association currently has two headquarters, one located at the Central Única dos Trabalhadores' (CUT) Campinas branch ${ }^{11}$ downtown and the other in the Jardim Itatinga, the largest open-air red light district in Latin America. During the thirteen years of the Association's existence, it has worked in partnership with several state and non-state bodies, organizing against police violence, segregation, closures of sex establishments, and

11 CUT is one of Brazil's oldest labor organizations, affiliated with the Workers' Party (PT). The branch office is one of many in the interior of the State of São Paulo, organizing the local unions. The CUT branch has been one of the Association's main partners since 2008, when the Association was recognized as a worker's organization and invited to participate in the CUT. This implies the AGM's support of and by all unions affiliated to the CUT. 
illegal arrest and harassment (Helene 2019). ${ }^{12}$ AMG's partnership with CUT is particularly important, due to the union's national presence and force, and fact that many state institutions have an abolitionist perspective of sex work. AMG's presence in CUT in Campinas has forced these institutions to review their stance.

Many thought that COVID-19 would severely disrupt the Jardim Itatinga's sex market. While some venues did close and the overall number of workers dropped (from about 1700 to 800), clients continued to come, prompting discussions at AMG about sex work as essential work and ways to ensure necessary protection and care for workers during the pandemic.

In the first fifteen days of Campinas' isolation decree in March, the number of clients in the district declined slightly. After that first fortnight, however, business returned to normal and even intensified. In general, Itatinga did not stop. The neighborhood was packed with clients, although some sex workers (such as co-author Santos) decided to reduce their hours and services, especially with elderly clients. Yet, as Santos shares, it got to a point where family members of clients were reaching out to her and requesting that she attend to their fathers and brothers. This led her to reflect upon how essential her work was for the physical and mental health of her clients:

A lot of people think that sex work is just having sex, receiving pay and that's it. It is much more! A lot of my clients are from the high risk group [for Covid]. They asked their children to get in touch with me to tell me how much their parents needed me. Daughters of clients sought me out, saying things like, "I'm Claudio's daughter. It's not a secret that he goes to see you once a week, my mom and I know. We prefer that you continue to see him because you are good for him". It was amazing, because lots of children, that I didn't even know existed, got in touch with me. Talking with other sex workers, we decided that sex work is essential work. The zona couldn't close because the clients sought us out!

Conscious of the essential and important nature of their work for their clients' wellbeing and of the need to protect their own health, the women of the AMG developed a series of activities to reduce vulnerability and guarantee the health of all workers in Jardim Itatinga. While they focused on the many diverse vendors and other workers in the district at the beginning of the pandemic, the AMG's main concern was protecting sex workers. In doing so, the Association ran into issues that are constitutive of sex work itself, migration, for example. A large number of women come into the district from different states and even other countries. Often, they outnumber the women from Campinas. In the specific case migrants, the AMG recognized that it was not always possible for them to stop working and return home. Since many venues were closed, many workers had to go to the houses that remained open. This risked crowding. AMG members worked with the women to find solutions to avoid crowding and promote prevention and social distancing measures to reduce the risk of contagion.

In talking with sex workers, the AMG realized that venues lacked the hygiene and cleaning supplies necessary to combat COVID-19. Basic supplies were being sold by vendors at exploitative prices, with many women paying 35 reais (7 USD) for a $250 \mathrm{~mL}$ bottle of alcohol gel. Customers would often bathe as soon as they arrived in the district, using the women's towels and soap. The AMG reached out to collaborators such as the Pastoral da Mulher Marginalizada (Marginalized Women's Pastoral-PMM) ${ }^{13}$ and other NGOs and Unions for assistance in raising donations and putting personal hygiene kits together in order to meet sex workers' needs. Through these partnerships and a crowd funding project together with the Coletivo Puta Davida in Rio de Janeiro, the AMG was able to assemble 365 prevention kits, allowing new prevention protocols to be put into place. Now, when customers arrive, they must wash their hands, drying them with paper towels

12 For more information on the Association's work, see (Tavares 2014; Bonomi 2019).

13 The Pastoral da Mulher Marginalizada is an NGO connected to several different social movements, as well as the Catholic Liberation Theology movement. It has progressive views on human rights issues, but is abolitionist with regards to prostitution, understanding it as one of the generative institutions of women's exploitation in capitalist society (Skackauskas 2014). 
and not the women's towels. Bleach and alcohol are used to sterilize rooms' welcome mats. Customers' shoes are cleaned and left outside the rooms. The use of baby wipes and masks were essential in minimizing women's direct contact with customers. Two masks are used: one to receive the customer and the other during the sex act itself. This is how the AMG managed to help Itatinga get through the most critical phase of the pandemic.

Charity programs are not part of the AMG's normal routine, but given the seriousness of the moment, they worked with the PMM to provide food for a daycare center (as school had been suspended) and donated meals from this project to women in Itatinga. Additionally, once a week, the Association receives and distributes food, allowing sex workers to cook in their respective rooms. Since the neighborhood Health Center is only open for emergencies, the AMG has also taken on the Center's task of delivering condoms and gel to sex workers. This is also an emergency policy for the Association policy, as it normally encourages workers and venue owners to get this material from the health authorities.

The AMG has carried out two initiatives to receive health and financial relief from the State: registering sex workers for emergency aid ${ }^{14}$ and for $\mathrm{H} 1 \mathrm{~N} 1$ vaccinations. This was done in partnership with CUT and was successful in securing the aid for trans- and foreign women. The second initiative pushed vaccination through the AMG's dialogue with the neighborhood Health Center, securing priority for H1N1 vaccine shots by having sex workers recognized as essential workers. The Association was also successful in taking this strategy to another city, Ribeirão Preto, where allies in the Vitória Régia sex worker organization managed to stimulate dialogues between the two cities' health centers.

Another action the Association took in the neighborhood in the early weeks of the pandemic was to convince house owners to exempt trans sex workers from paying daily rent. The houses offer breakfast, lunch, and living space for many who work there (this is one of the reasons the Association compares sex work with domestic work: they are similar in their internal dynamics). The house owner agreed that if the city decreed social isolation, she would announce 15 days of exemption from payment of daily rates for her residents. The district itself did not stop, but the owner maintained her agreement with the Association, in part thanks to the Gabriela Leite Bill. Association members always carry a copy of this with them and it serves as a warning, because house owners believe that they might one day be fined if they get too exploitative.

In this way, the pandemic has contributed to connecting sex entrepreneurs and sex professionals. For the first time in the history of Itatinga, the AMG has managed to bring together over seventy house owners and workers to change some of the neighborhood's routines to avoid conflicts with the military police and to reduce agglomerations. As the city's leisure venues have closed, many young people come to Jardim Itatinga to hear music. When the Association realized that the police were increasing their presence in the neighborhood, it organized a meeting to convince house owners to turn down the music and thus avoid crowds and police violence. The women of the Association also asked sex workers not to talk at curbside with potential clients in order to avoid contagion.

\section{2. "We Are the Seeds of Marielle, Sprouting against Bolsonaro": Rio de Janeiro, CasaNem}

CasaNem is an urban squat and educational and cultural project for the LGBTQIA+ community that plays a particularly central role in radical activism and essential services for travestis and trans people in Rio de Janeiro. It was created and is led by co-author Indianarae Siqueira, a vegan transvestigênere whore, founder of the NGO Transrevolução, supplementary city councilmember, and a member of the Coletivo Puta Davida and Brazilian Prostitutes' Network.

The squat evolved out of PrepareNem, a college prep program for trans people started by Siqueira. For nearly five years, between 2015 and 2020, the squat occupied and was evicted from a series of abandoned buildings before joining up with FIST (the International

14 This is an emergency directed towards informal laborers, micro-entrepreneurs, independent workers, and the unemployed. Its goal is to provide emergency financial aid during the COVID 19 crisis. For more information, see https://auxilio.caixa.gov.br/\#/inicio. 
Homeless Front) and arriving in Rio de Janeiro's "postcard" neighborhood, Copacabana, in 2019. There, they occupied a seven-story abandoned apartment building, one of the first modern buildings to have been built in the neighborhood. While reconnoitering the premises, the women found an abandoned collection of art and archeological objects (including a mummy), which they turned over to Brazil's National Patrimony Agency (IPHAN), the National Museum, and the Federal Police. The women cleaned and organized the building and, for a while, it seemed as if CasaNem would have a bit of peace in recognition of their service to society. ${ }^{15}$

CasaNem's residents see themselves as seeds and take the spirit of assassinated city councilwoman Marielle Franco with them wherever they go. Even prior to the Covid-19 pandemic, they organized and distributed fruit, bread, food, and water to meet the needs of those who had been abandoned. Survival was also nourished by the hope of a better world for everyone. When the world suddenly stopped with the pandemic, CasaNem built on all that they had been doing and were concretely prepared to expand their aid network.

Building on Siqueira's network with LGBTQIA+ and HIV / AIDS groups, she organized a meeting in April of 2020 with all of the LGBTQIA+ shelters in Brazil and together they formed a national network of shelters to create mutual aid and support. Called REBRACA (Rede de Acolhimento para LGBTQIA+ no Brasil - Network to Take In LGBTQIA+ in Brazil), it exists in all Brazilian states, meaning that LGBTQIA+ can have the space to safely fully live their sexuality and gender in the case of violence in their homes and/or from family members.

While Brazil seemed lost, CasaNem took upon itself the responsibility of protecting the most vulnerable in society, including animals. The 65 residents of the squat in Copacabana organized the building to be able to take in people who had nowhere to go during lockdown, establishing an entire floor as quarantine for new residents. They organized a series of successful crowd funding campaigns, proving that another world is possible through their network of collaborators and friends. To date, they have distributed more than 3500 monthly food ration packs with hygiene and cleaning kits to the LGBTQIA+ community, sex workers, and poor communities on the outskirts of Rio de Janeiro. Through collaborations with other NGOs, they participated in the project, "Mascaras do Bem" (Masks for Good), sewing and donating 20 thousand protective masks to those who needed them, in addition to clothes and food for the homeless and their animal companions. It was exhausting work, but also essential.

Despite providing these vital public services, the State moved once again on CasaNem in August 2020. Heavily armed police blockaded the squat's Copacabana residence. In front of the T.V. cameras, the residents proclaimed that either the State would make a peaceful deal with them, or they would fight to the last drop of blood to keep their home. Barricades went up in the squat and, outside its gates, protesters gathered to stand vigil with CasaNem, while some neighborhood residents sided with the police.

Faced with bloodshed on the nightly news and the shame of throwing vulnerable people into the streets in the midst of a pandemic, the state government of Rio de Janeiro agreed to temporarily settle CasaNem in an unoccupied school. The collective accepted the offer, but once installed, they were attacked by neighbors and suffered warrantless raids by the police, resulting in Siqueira's temporary arrest.

Finally, after much struggle and pressure, in September CasaNem received the keys to what the state and city of Rio de Janeiro, through the Rio Sem Homofobia (Rio without Homophobia) program and the Coordenadoria Especial de Diversidade Sexual (Special Office on Sexual Diversity), respectively, have assured them will be its permanent home: a large yellow, two story house that previously housed an Evangelical church. The "faggots, dykes, Transvestigeneres, TransAgeneres, and fighting whores" of CasaNem moved into their new installations. As Indianarae frequently says, "Evangelical churches have been taking

15 This was widely covered and recognized by the media. For one example, see: https://g1.globo.com/rj/rio-de-janeiro/noticia/2019/07/20/acervoartistico-e-ossada-sao-achados-em-predio-abandonado-em-copacabana.ghtml. 
territory away from social movements, gay cinemas, and clubs forever. Now the CasaNem is taking these back".

This conquest of a permanent space is an excellent example of how CasaNem has successfully negotiated an ambiguous role, partnering with city and state governments currently under Evangelical leadership while also pushing the limits of the law through squatting abandoned buildings and calling for a pro-whore, trans, LGBTQIA, vegan, and police-free urban order. In the current contentious and polarized climate, partnerships with the state government have been facilitated by Governor Wilson Witzel's son Erick Witzel, who is a trans man and made headlines through his outreach and support to the CasaNem through the city's Sexual Diversity office (Calixo 2020).

Yet, as a squat, at its heart CasaNem is an anti-capitalist organization aligned with many leftist groups such as unions and political parties. They have noticed, however, that socialists and social democrats do not seem prepared to deal with or understand prostitution. This has largely to do with differing philosophies regarding sex work: Indianarae and residents of CasaNem tend to see prostitution in more anarcho-naturalist terms, in contrast with the more union-oriented view of Campinas' Warrior Women Association, described above.

Siqueira believes that prostitution will not end with the arrival of the socialist revolution, taking a position that sexuality is a natural activity, necessary for the maintenance of mental and emotional health. In her view, then, sex work is not just essential work: rather it is literally ineradicable, even under conditions of total class and gender equality, much in the same way as cooking or childcare.

This is why social movements have trouble with me. They want to place people in the formal job market, right? Every time, it's: 'The only option for travestis and transsexuals can't be prostitution', as if prostitution were a bad thing. This bothers me a lot. 'Damn, why talk about prostitution like that?', I ask. If people had prostitution as their only option, they wouldn't be going into prostitution: they'd be fighting for access to other work. But the reality is that more can be made in prostitution because you only need the experience of your body! You don't need any other experience. You just let your body speak and act. The labor is you; the whole input is you. Sex is natural. It's natural for me to put a price on sex since we live in a capitalist society. I should receive for what I do, even if I like it. It's not just me who wants it: other people want it. And since someone else also wants it, I'll naturally put a price on it. Prostitution is one of the more natural jobs that exists.

Prostitution, for Siqueira, is about anarchism, using essential resources justly, and fomenting freedom. In this view of a possible future, nobody rules anyone; nobody is a boss. A self-taught historian of both social movements and prostitution, Siqueira notes that socialism and anarchism have been (re)created by legions of free women who claimed their own sexuality and did not want to get married. These free women are the people she sees as the historical leaders of revolutions: "They were called "whores", these women who didn't want a home, who practiced their sexuality freely or who exchanged sex to survive. The revolution has always been led by whores".

\subsection{Vila Mimosa Red Light District, Rio de Janeiro}

Vila Mimosa is one of the oldest red light districts in Brazil, with a history closely tied to sex worker activism and repression and control of prostitution in Rio. The municipal government created the district in the 1920s in an effort to shift prostitution from Rio's city center to a single regulated, contained area in preparation of a visit from the King of Belgium (Simões 2010a). In 1987, the government once again relocated the Vila to make way for a radio-television station, but Gabriela Leite's recently formed prostitute movement organized resistance against the decision. The sex worker movement had a strong base of activism in "VM" during the late 80 s and early 90s, holding off the second relocation for nearly ten years. In 1996, however, the Vila moved to its current location as part of a gentrification process of the entire area where it had been located. 
The legal structure of the businesses in the Vila is somewhat complex, and has been described by anthropologists Soraya Simões (2010b) and Elisiane Pasini (2005). There is a large warehouse containing dozens of bars that is legally owned by a small group that has registered it as a generic commercial enterprise. Individual bars are "owned" via contracts made with the warehouse owners - contracts that do not exist outside of the Vila Mimosa. "Bar owners" do not directly make money off of prostitution. Instead, they rent tiny private rooms to sex workers and their clients. Across the street from the main warehouse are some dozen more establishments with slightly better infrastructures, run in the same fashion as their more precarious counterparts. Prostitutes work wherever and whenever they want, without obligations in terms of hours or having to pay a cut of their programs to bar owners. While this autonomy has many advantages and is one of the main draws for sex workers to the Vila, co-author Cristiane Oliveira who has worked in the Vila for ten years also notes that in general, the owners only see prostitutes as a "source of money", profiting from room rentals and alcohol.

There is no sex worker-led activism in the "new" Vila Mimosa. After the 1996 move, activism reorganized around the formation of AMOCAVIM (Associação de Moradores do Condominio e Amigos da Vila Mimosa - the Association of Residents and Friends of the Vila Mimosa Condominium). The Association primarily represents the legal and economic interests of business owners, while also supporting professional training, HIV testing, and other sexual health-related interventions for sex workers. AMOCAVIM does not press for the decriminalization or regulation of sex work, and occasionally uses the abolitionist term "women in prostitution" in their projects as opposed to "sex workers" or "prostitutes". They deal with the police, the Human Rights and Women's Secretariats, researchers, the Health Department and any legal issues in addition to financing and managing humanitarian projects in and around the Vila. Like many NGOs in Brazil, AMOCAVIM has considerably reduced their activities in the past five years as funding has dried up and economic crises have intensified.

Municipal and state authorities have largely abandoned Vila Mimosa with the exception of several spectacles, staged to give the appearance of fighting human trafficking during the World Cup and Olympics (Mitchell Forthcoming; Murray et al. 2018b). Things changed in December 2019, when a police operation ordered by a Rio de Janeiro State Legislative Assembly committee, commanded by Rodrigo Amorim (a reactionary state legislator famous for publicly destroying a street sign paying homage to Marielle Franco), shut down the Vila, putting some 4000 sex workers into the streets. The alleged reasons for VM's closing were that it was both a fire and health hazard (although the city had ignored conditions in the Vila for nearly three decades). For months on end, all the laborers who depended on the Vila for their livelihood-sex workers, bartenders, street vendors, service workers -were out of work. Many sex workers, such as Cristiane, sought other labor such as housecleaning, while continuing to work at other venues and with steady clients. The situation for many sex workers was desperate, however. They had no idea where to go or how they were going to make ends meet.

AMOCAVIM organized a public pressure campaign against the closure, which included a bloco (street parade) during Carnival (Figure 1). This playfully updated "Rosie the Riveter" with the hashtag of \#letmommywork. The image and tag reinforced the message that many sex workers in the Vila are mothers, working to support their families. At the bloco, protestors carried signs reinforcing this message: "We want to work! We have children to raise!" Sex workers participated in the bloco along with other activists, but they did not take a public leadership role in expressing their demands.

AMOCAVIM and its lawyers were able to pressure Amorim to hold a public hearing on 13 March, 2020, about the situation, with representatives from the state legislature, fire department, sex workers, and other interested parties. Amorim began the hearing by showing a series of photographs from his report. These included the precarious and illegal electrical wiring systems in the cubicles where sex workers attend clients. He commented on the images, stating, "I know it isn't the focus of this investigation, but look at the level 
of human degradation in this place!" Images of condoms on the floor, narrow hallways, and Afro-Brazilian religious alters with candles and food left out at one of the restaurants, were also used as evidence of what Amorim referred to as the "dangerous", "inhuman", and "grotesque" nature of Vila Mimosa.

The stigmatizing nature of Amorim's presentation and his insistence that he sought to dignify the "desperate mothers" working to support their families (several of whom were present yet did not speak at the hearing) was questioned by attorneys and Vila supporters. These pointed out that the legalities required by the ALERJ committee were not required of other institutions, such as the ALERJ itself (the room where the public hearing was held did not have any signs indicating exists or fire extinguishers). Despite its apocalyptic language, the hearing ended on an optimistic note regarding re-opening. Three days later, however, the Governor of Rio de Janeiro instituted a lockdown, due to the alarming rise in COVID-19 cases. Once again, Vila Mimosa was thrown into chaos.

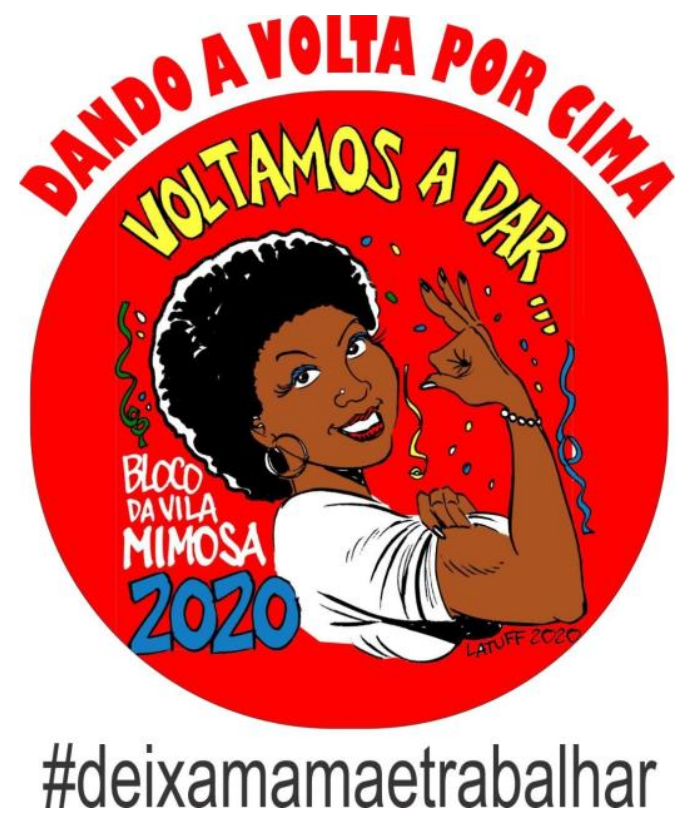

Figure 1. Vila Mimosa bloco artwork. "Turning things around", "We're back putting out", \#letmommywork. Downloaded from Amocavim's Facebook page.

During the first few weeks of the pandemic, several of the Vila's bars remained open, despite government orders. It was a time of "a lot of confusion", as two sets of government orders coincided - those from the Legislative committee, and those regarding the pandemic. Police patrolled the Vila around the clock, conducting raids and forcing bars to close under the guise of fire department orders and enforcing the lockdown. AMOCAVIM organized crowdfunding campaigns and mobilized their partners to provide food and cleaning products to the Vila's workers and residents. The campaign emphasized that the Vila also needed to quarantine, but that to be able to do that, it needed the support of others. The campaign's Facebook post ${ }^{16}$ emphasized that "our women are the ones who most suffer from stigma and exclusion, because many are heads of households". It also mentioned past work training programs conducted in the Vila through which "many women left prostitution", continuing that, "we know their potential and want to strengthen and support our women".

AMOCAVIM was able to mobilize support, but not nearly enough for the 4500 families that depend on the Vila. As such, some sex workers, including co-author Cristiane Oliveira, continued working during period. As she says, "we had to stay together and united,

16 https://www.facebook.com/associacaovilamimosa/posts/1530139713821126?_tn__=K-R 
working in the places that remained open". She and several of her colleagues ended up sick, testing positive for COVID-19. For forty days she quarantined, prior to returning to the Vila to work once she was healthy. Back at work, Olveira uses two masks and alcohol gel. Clients wash their hands and take off their shoes prior to entering the rooms. The air conditioners have been turned off and bar owners provide alcohol gel, but she notes that "many people aren't worried at all" and do not use masks.

Oliveira agrees with Siqueira that prostitution is natural, and also with Santos that it is "a job like any other". As she says, "People want sex and people want money. It's a natural thing, it's an exchange. But [sex workers] should have some privileges especially in terms of health: like vaccines, STD and HIV exams".

In this way, Oliveira also sees that taking care of herself and her health is one of the fundamental components of sex work. Yet while she sees prostitution as work, like many of her colleagues in the Vila, she chooses not to register as a sex worker under the CBO. She says that if prostitution were regulated, she would not sign the carteira de trabalho ${ }^{17}$ due to prejudice from society and her family.

\section{Discussion}

Looking at the three case studies in light of the considerations of the first half of the article, we are able to see how the logic underpinning public policy with regards to prostitution in Brazil-“unregulated regulation" — has resulted in highly differentiated and localized forms of sex work administration across contexts and, in turn, diversified forms of resistance and organization by sex workers. The patchwork of policies regarding COVID-19 resulting from the Bolsonaro's "(non)governance" of the pandemic has not only reinforced Brazil's tradition of "unregulated regulation" with regards to prostitution: it has also meant that sex workers once again took on a fundamental role in organizing local responses to a health crisis by building on pre-existing alliances and enmities as the State assumed contradictory roles even within the same city.

This is perhaps best shown in the two case studies from Rio de Janeiro. CasaNem, for example, began the pandemic occupying their squat in Copacabana in a state of uneasy truce with local authorities. Shortly after the crisis began, however, police repression ramped up, resulting in the collective's expulsion and subsequent harassment and almost ending in open, violent confrontation between CasaNem and Rio's notoriously deadly police. However, the intense pressure and political consequences of an eviction in the middle of a pandemic combined with Indianarae's strong relationship with LGBTQIA+ diversity programs in the municipal and state human rights secretariats (including the support of the governor's son) facilitated a peaceful resolution of the showdown and, ultimately, the apparently permanent settling of CasaNem in the Flamengo neighborhood.

Meanwhile, Vila Mimosa began the crisis interdicted by State authorities due to "safety concerns". Some of the same politicians who maneuvered to shutter the Vila, in fact, are President Bolsonaro's staunchest local allies. Apparently, then, the poor of Brazil really did not need to continue working, in the eyes of these gentlemen, until COVID-19 threatened to close down the entire Brazilian economy. Nor did the "concern for women's health", so prominent in the public hearings around Vila Mimosa in the arguments favoring its interdiction before the pandemic, result in any State aid to the workers of the Vila after Rio began social isolation. Instead, the women continued to be harassed by the police, but were then allowed to return to work with no provision being made for their or their clients' health. Today, VM's future is uncertain and seems to be largely dependent on AMOCAVIM's ability to unilaterally negotiate with State and parastatal entities. In Campinas, by contrast, earlier "marriages" with unions, political parties, and the Catholic Church were mobilized in order to provide AMG with the physical/financial inputs and the moral/political capital to meet the pandemic head on and organize both workers and house owners in Itatinga to create a common front of resistance, labor, and care.

17 Workers' card, where all work sanctioned by labor laws is formally registered in an individual paper book. 
What is most striking about each of the three cases described here, however, is the fact that each group of prostitutes' conception of labor is different, even though all consider sex work to be essential work. All three groups have their historical roots in the responses and solutions created by sex workers' alliances with the Brazilian government in the face of the HIV / AIDS epidemic, when prostitutes were called upon to formulate and support State prevention policies. Warrior Women and CasaNem, however, always saw this as part of a larger struggle involving workers', women's, and sexual rights. Vila Mimosa, dominated as it is by the brothel owners' interests, never moved beyond a purely assistentialist attitude, exemplified by the association's frequent characterization of prostitutes as social victims and its position against regulation. In AMOCAVIM's view of things, sex work exists to provide a minimum of sustenance to women who have no other choice in the world - both morally/politically and in terms of labor. From sex workers' perspectives, the support provided by AMOCAVIM for humanitarian, health, and pandemic related mobilizations of food and hygiene kits is welcome and important, but a far cry from a labor and prostitutes' rights based organization. In this context, it is not surprising that there continues to be widespread sex worker reticence around registering as professionals with the Ministry of Labor and taking a more public stance for prostitute rights.

All three case studies point to sex work as essential work. Essential in the sense that the author from Warrior Women establishes, in that it must continue in order for other labor to be conducted and family structures to be maintained. This is an understanding of sex work that follows Marx's observation that certain cultural elements are necessary for labor's reproduction: "beer is necessary for the reproduction of the working class in England, just as wine is in France" (Marx, apud Rubin 1975, p. 163). Santos observes that, at least for the men of Campinas, the purchase of sex outside of the bounds of heterosexual reproductive monogamy seems to fall into just this sort of category. But sex work is also essential in a specific Brazilian history, wherein it is linked to a tradition of community care-particularly of communities that are marginalized and excluded due to their sexual practices, but also to the recognition of these communities as educators of those "good families" the Bolsonaro government so loves to talk about. But if all three groups see sex work as essential, the case studies also illustrate important nuances between how they view and organize around work as a political category.

Warrior Women, in Campinas, exemplifies a socialist-syndicalist view of sex work as socially organized productive labor in the Marxian sense of the term, along the lines of Rosa Luxemburg's observation that "the dancer in a cafe, who generates profits for her employer with her legs, is a productive worker" (Luxemberg [1912] 1971). Here, grassroots organization of laborers, both for mutual aid and for leveraging power in the face of venue owners, backed up by the full force of one of Brazil's largest labor unions, has been crucial for sex workers to weather the pandemic's storm.

CasaNem, meanwhile, takes a much more anarcho-feminist approach to sex work, one that is heavily anchored in the traditions of Brazil's LGBTQIA+ communities. Here, sex is seen as a form of naturalized, embodied individual labor, which can be exchanged in Kropotkian networks of mutual aid. In this anarcho-socialist tradition (in which the author is rooted), sexual labor is understood to be an expression of individual will and desire, democratically and socially organized according to the dictum of "no bosses".

Both groups' relative success, however, is also due to their deft formation of alliances with local instances of State and parastatal power (as well as their engagement with prostitution's own history of being a parastatal ally of the Brazilian public health system), even if these are not willing or able to recognize prostitution as work. This is the case of Warrior Women's "marriage" with the Pastoral da Mulher Marginalizada and the Workers" Union CUT: both formally abolitionist in outlook. The same phenomenon can be seen in CasaNem's employment of one branch of the Rio de Janeiro state government (the Human Rights Secretariat) to out-maneuver the same state government's armed security agents (the Military Police). Although socialist in their approach to labor, then, both groups are willing to employ the long-established Brazilian politics of personal patronage and 
alliance to achieve their goals, even when said alliances might be seen as contradicting their political stance regarding work.

Meanwhile, both business owners and sex workers in the Vila Mimosa seem to rely almost entirely on the politics of personal patronage and legal maneuvers for survival. The essentiality of sex work, at least in rhetoric of AMOCAVIM, is that it is a means of survival and for women to support their families. Of the three cases studied, Vila Mimosa is the only one that does not have a robust, grassroots sex worker organization. It is organized more like a "company union": sex workers are convocated to show up for demonstrations but are not part of the governing structure. Faced with this situation, sex workers must employ what James Scott calls "the weapons of the weak" (Scott 1985) and seek individual or small-group solutions through personal networks and clients (especially in the case of financial resources), usually without directly challenging power.

\section{Conclusions}

On December 9, the day that we are finalizing this manuscript, three coinciding events are illustrative of the kind of necropolitics that has come to define both gender and public health policy in Brazil. First, as COVID-19 deaths neared 180,000 and other countries were organizing to vaccinate, Bolsonaro proudly showed how he was more concerned about importing guns than vaccines, posting a photograph of himself on Instagram at a firing range along with news that he had just edited a resolution to take away all taxes on revolvers imported into the country. Second, as prices on basic food staples such as rice and beans soared, Bolsonaro's University of Chicago educated Minister of the Economy Paulo Guedes confirmed that the government would be ending its emergency financial assistance at the end of the year. And last and very sadly, we received news that a sex worker who worked on the street just outside the Vila Mimosa was brutally murdered, leaving two children without a mother. Her death did not make the news, and has inspired fear in the Vila Mimosa. In all three examples, the exposure to death, threat of death, and death itself clearly manifest as part of a gendered necropolitics that has left sex workers especially vulnerable.

The actions and responses of the various sex work networks in Brazil in the face of COVID-19 have been similar in their vital importance while also different in their strategies. Their fields of action depended both on previously established political alliances and their clear perceptions of themselves as workers in the social sense. This understanding not only of sex work as essential work, but also their activism as essential work will be even more important in the months and years to come. The debate on the recognition of prostitution as labor is threatened by a context in which labor rights themselves are being destroyed and much of the economically active population is shifting to informal work without rights, much closer to the type of "labor regime" that has traditionally governed prostitution in Brazil. Within such a context, no group is better prepared than sex workers to lead projects of social change. As Indianarae Siquiera reminded us here, "The revolution has always been led by whores".

Author Contributions: B.S.; L.M.; C.B.; A.P.d.S. and T.B. conceptualized the article and developed an outline that guided the entire process. B.S.; I.S.; C.O.; C.B. and L.M. researched and wrote the case studies. T.B. and C.B. wrote the sections on the law, labor and current context and S.S. and A.P.d.S. wrote the sections focused on $\mathrm{CBO}$ and discussion of the three case studies, respectively. L.M. was responsible for the manuscript as a whole and tying the sections together in the Introduction and Conclusions. All authors contributed to the overall manuscript and approved the final version. All authors have read and agreed to the published version of the manuscript.

Funding: This research received no external funding.

Institutional Review Board Statement: Not applicable.

Informed Consent Statement: Not applicable. 
Data Availability Statement: No new data were created or analyzed in this study. Data sharing is not applicable to this article.

Conflicts of Interest: The authors declare no conflict of interest.

\section{References}

ABIA, and DAVIDA. 2013. Analysis of Prostitution Contexts in Terms of Human Rights, Work, Culture, and Health in Brazilian Cities. Rio de Janeiro: Brazilian Interdisicplinary AIDS Association-ABIA.

Ahmetbeyzade, Cihan. 2008. Gendering necropolitics: The juridical-political sociality of honor killings in Turkey. Journal of Human Rights 7: 187-206. [CrossRef]

Amar, Paul. 2013. The Security Archipelago: Human-Security States, Sexuality Politics and the End of Neoliberalism. Durham: Duke University Press.

Blanchette, Thaddeus, and Cristiane Pereira. 2017. Sex Work in Rio de Janeiro: Police Management Without Regulation. In Selling Sex in the City: A Global History of Prostitution, 1600s-2000s, 1st ed. Edited by Magaly Rodriguez Garcia, Lex Heerma Van Voss and Elise Van Nederveen Meerkerk. Leiden: Brill, vol. 31, pp. 490-518.

Blanchette, Thaddeus, Gregory Mitchell, and Laura Murray. 2017. Discretionary Policing, or the Lesser Part of Valor: Prostitution, Law Enforcement, and Unregulated Regulation in Rio de Janeiro's Sexual Economy. Criminal Justice and Law Enforcement: Global Perspectives 7: 31-74.

Bonomi, Carolina. 2019. Mulher da Vida: É Preciso Falar: Um estudo do movimento organizado de trabalhadoras sexuais. Master's dissertation, Social Sciences, State University of São Paulo (UNICAMP), São Paulo, Brazil.

Calixo, Bruno. 2020. Coronavírus Erick Witzel, filho do governador, e Prefeitura do Rio entregam cestas básicas à projeto que acolhe LGBTs. O Globo Rio. Available online: https:/ / oglobo.globo.com/rio/coronavirus-erick-witzel-filho-do-governador-prefeiturado-rio-entregam-cestas-basicas-projeto-que-acolhe-lgbts-24330985 (accessed on 10 September 2020).

Carrara, S. 1996. O Tributo a Venus: A Luta Antivenérea no Brasil de Finais do Século XIX até os Anos 40. Rio de Janeiro: Casa Oswaldo Cruz Publications.

Chaloub, Sidney. 1996. Cidade Febril: Cortiços e Epidemias na Corte Imperial. São Paulo: Companhia das Letras.

De Lisio, Amanda. 2013. Event Urbanism and the Politics of Enthusiasm. Scapegoat Journal: Architecture, Landscape and Political Economy 5: 170-79.

Dewey, Susan, and Patty Kelly, eds. 2011. Policing Pleasure: Sex Work, Policy, and the State in Global Perspective. New York: NYU Press.

Gichuna, Susan, Rahma Hassan, Teela Sanders, Rosie Campbell, Mercy Mutonyi, and Peninah Mwangi. 2020. Access to Healthcare in a time of COVID-19: Sex Workers in Crisis in Nairobi, Kenya. Global Public Health 15: 1430-42. [CrossRef] [PubMed]

Guimarães, Raphael Mendonça, Tatiana de Araujo Eleuterio, and José Henrique Costa Monteiro-da-Silva. 2020. Estratificação de risco para predição de disseminação e gravidade da COVID-19 no Brasil. Revista Brasileira De Estudos De População 37: 1-17. [CrossRef]

Helene, Diana. 2019. Mulheres, Direito a Cidade e Estigmas de Gênero: A Segregação Urbana da Prostituição em Campinas. São Paulo: Annablume.

Lam, Elene. 2020. Pandemic sex workers' resilience: COVID-19 crisis met with rapid responses by sex worker communities. International Social Work 63. [CrossRef]

Leite, Gabriela. 1996. The prostitute movement in Brazil: Culture and religiosity. International Review of Mission 85: 417-26. [CrossRef]

Leite, Gabriela. 2009. Filha, Mae, Avo e Puta: A Historia de uma Mulher que Deidiu ser Prostituta. Rio de Janeiro: Objetiva.

Leite, Gabriela. 2013. Porque Gabriela Prefere a Palavra Puta/Why Gabriela Prefers the Word puta/whore. Available online: https:/ / www.youtube.com/watch?v=CvKkGPiXv0o (accessed on 30 September 2020).

Leite, Gabriela, Laura Rebecca Murray, and Flavio Lenz. 2015. The Peer and Non-peer: The potential of risk management for HIV prevention in contexts of prostitution. Revista Brasileira de Epidemiologia 15: 7-25.

Luxemberg, Rosa. 1971. Womens Suffrage and Class Struggle. In Selected Political Writings. Edited by Dick Howard. New York: Monthly Review Press. First published 1912.

Mac, Juno, and Molly Smith. 2018. Revolting Prostitutes. London: Verso.

Marques, Emanuele, Claudia Leite de Moraes, Maria Helena Hasselmann, Suely Ferreira Deslandes, and Michael Eduardo Reichenheim. 2020. A violência contra mulheres, crianças e adolescentes em tempos de pandemia pela COVID-19: Panorama, motivações e formas de enfrentamento. Cadernos de Saúde Pública 36: e00074420. [CrossRef] [PubMed]

Mbembe, Achille. 2003. Necropolitics. Public Culture 15: 11-40. [CrossRef]

Mitchell, Gregory. Forthcoming. 40,000 Missing Girls: Moral Panics, Global Sporting Events, and the Spectacle of Sex Trafficking. Edited by Marlon Bailey and Jeffrey McCune. New Sexual Worlds. Berkeley: University of California Press.

Murray, Laura. 2014. Victim Management and the Politics of Protection: Between "Fazer direito" and "direitinho". Revista Artemis XVIII: 28-41. [CrossRef]

Murray, Laura Rebecca, Deanna Kerrigan, and Vera Paiva. 2018a. Rites of Resistance: Sex Workers' Fight to Maintain Rights and Pleasure in the Centre of the Response to HIV in Brazil. Global Public Health Special Issue on Latin American Social Movements 14: 939-53. [CrossRef] [PubMed]

Murray, Laura, Ana Paula da Silva, Angela Donini, and Cristiane Oliviera. 2018b. Shifting Gazes and Challenging Discourses about Sex Work and Mega-events in Brazil. In International Handbook on Sex Industry Research: New Directions and Perspectives. Edited by Isabel Crowhurst Susan Dewey and Chimaraoke Izugbara. New York: Routledge. 
Ortega, Francisco, and Michael Orsini. 2020. Governing COVID-19 without government in Brazil: Ignorance, neoliberal authoritarianism, and the collapse of public health leadership. Global Public Health 15: 1257-77. [CrossRef] [PubMed]

Pasini, Elisiane. 2005. Sex for almost all: Female prostitution in Vila Mimosa. Cadernos Pagu 25: 185-216. [CrossRef]

Platt, Lucy, Jocelyn Elmes, Luca Stevenson, Victoria Holt, Stephen Rolles, and Rachel Stuart. 2020. Sex workers must not be forgotten in the COVID-19 response. Lancet 396: 9-11. [CrossRef]

Prada, Monique. 2018. Putafeminismo. São Paulo: Veneta.

Rede Brasileira de Prostitutas. 2011. Deliberações: Não Queremos Mentiras Faladas, Queremos ser Felizes. Somos Profissionais, se Assim nos Chamam, do Sexo e não do Governo. Paper presented at Encontro Regional de Belém sobre DST/HIV/AIDS e Hepatites Virais, Belém, Brazil, August 6.

Rubin, Gayle. 1975. The Traffic in Women: Notes on the "Political Economy" of Sex." Toward an Anthropology of Women. Edited by Rayna R. Reiter. New York: Monthy Review Press, pp. 157-210.

Sánchez, O. R., D. B. Vale, L. Rodrigues, and F. G. Surita. 2020. Violence against women during the COVID-19 pandemic: An integrative review. International Journal of Gynecology $\mathcal{E}$ Obstetrics 151: 180-87.

Sanders, Teela, Maggie O’Neill, and Jane Pitcher. 2017. Prostitution: Sex Work, Policy \& Politics. New York: SAGE.

Santos, Hebert Luan Pereira Campos, Fernanda Beatriz Maciel, Kênia Rocha Santos, Dídia Dayara Silva da Conceição, Rita Silva Oliveira, Natiene Ramos Ferreira da Silva, and Nília Maria de Brito Prado. 2020a. Necropolitics and the impact of COVID-19 on the Black community in Brazil: A literature review and a document analysis. Ciência E Saúde Coletiva 25: 4211-24.

Santos, Marcia Pereira Alves, Joilda Nery, Emanuelle Goes, Andreia Santos, Luís Eduardo Batista, and Edna Araújo. 2020b. População negra e COVID-19: Reflexões sobre racismo e saúde. Estudos Avançados 34: 225-44. [CrossRef]

Scott, James. 1985. Everyday Forms of Peasant Resistance. New Haven: Yale University Press.

Simões, Soraya. 2010a. Identidade e política: A prostituição e o reconhecimento de um métier no Brasil. Revista de Antropologia Social dos Algunos do PPGAS-UFSCar 2: 24-46.

Simões, Soraya. 2010b. Vila Mimosa: Etnografia da Cidade Cenografica da Prostitucao Carioca. Rio de Janeiro: Editora da UFF.

Skackauskas, Andreia. 2014. Prostituição, Gênero e Direitos: Noções e Tensões nas Relações Entre Prostitutas e Pastoral da Mulher Marginalizada. Ph.D. dissertation, Universidade Estadual de Campinas, Campinas, Brazil.

Souza Lima, Antonio Carlos. 2002. Sobre gestar e gerir a desigualdade: Pontos de investigação e diálogo. In Gestar e Gerir: Estudos para uma Antropologia da Administração Pública no Brasil. Edited by Antonio Carlos Souza Lima. Rio de Janeiro: Relume Dumará, pp. 11-22.

Szwarcwald, Celia, Giseli Nogueira Damacena, Paulo Roberto de Souza-Júnior, Mark Drew Guimarães, Wanessa da Silva de Almeida, Arthus Pate de Souza Ferreira, and Ines Dourado. 2018. Factors associated with HIV infection among female sex workers in Brazil. Medicine 97. Available online: https:/ / www.ncbi.nlm.nih.gov/pmc/articles/PMC5991538/ (accessed on 21 December 2020).

Tavares, Aline. 2014. A Organização da Zona: Notas Etnográficas Sobre Relações de Poder na Zona de Prostituição Jardim Itatinga, Campinas-SP. Campinas: Institute of Philsophy and Human Sciences UNICAMP.

Wright, Melissa W. 2011. Necropolitics, narcopolitics, and femicide: Gendered violence on the Mexico-US border. Signs: Journal of Women in Culture and Society 36: 707-31. [CrossRef] [PubMed]

Zanotti, Lia. 2020. From the Time of Rights to the Time of Intolerance. The Neoconservative Movement and the Impact of the Bolsonaro Government. Challenges for Brazilian Anthropology. Vibrant: Brazilian Virtual Anthropology 17: e17458. 